Max-Planck-Institut für demografische Forschung

Max Planck Institute for Demographic Research

Konrad-Zuse-Strasse 1 - D-18057 Rostock · GERMANY

Tel +49 (0) 3812081 - 0; Fax +49 (0) 3812081 - 202;

http://www.demogr.mpg.de

MPIDR WORKING PAPER WP 2006-001

FEBRUARY 2006

\title{
The third Child \\ A comparison between West Germany and Norway
}

David Alich (alich@demogr.mpg.de)

This working paper has been approved for release by: Gerda Ruth Neyer (neyer@ demogr.mpg.de) Deputy Head of the Laboratory of Contemporary European Fertility and Family Dynamics.

(C) Copyright is held by the authors.

Working papers of the Max Planck Institute for Demographic Research receive only limited review. Views or opinions expressed in working papers are attributable to the authors and do not necessarily reflect those of the Institute. 


\section{THE THIRD CHILD}

A comparison between West Germany and Norway

David Alich

Correspondence address:

David Alich

Max Planck Institute for Demographic Research

Konrad-Zuse-Strasse 1

D - 18057 Rostock

alich@demogr.mpg.de 


\section{Introduction}

The aim of this paper is to provide insights into third-birth dynamics in West Germany and Norway. This issue is important as the Total Fertility (TFR) of most European countries today is below the replacement level (2.1 children per woman). Families with two children dominate in Norway as well as in West Germany (Huinink 1988; Kravdal 1990). Taking into account the widespread two-child norm, we assume that three-child mothers form a special group with different motivations and fertility ideals (Berinde 1999).

The third-birth propensity in Norway and West Germany differs remarkably. The gap between the two countries is even larger when we take a look at women's perceptions of the ideal family size. In the datasets analyzed, nearly half (48 percent) of all Norwegian women perceive a family with at least three children to be an ideal size, in contrast to only 19 percent in West Germany.

We seek to address the following questions in this paper: What are the characteristics of mothers with two and three children? What are the differences in third-birth dynamics between Norway and West Germany, and how can they be explained? Which factors have a similar influence on Norwegian and West German two-child mothers and their further fertility? We believe that a comparison of thirdbirth behavior between Norway and West Germany is of interest since the two nations are examples of two different European welfare state regimes. Therefore, they can serve as an example to point out the effects of socio-economic characteristics under different societal settings.

We apply an event-history analysis to data from the Norwegian and German Fertility and Family Surveys (FFS). The Norwegian data was collected at the end of the 1980s, the German data at the beginning of the 1990s. Nearly the same 
questionnaire was used in both countries. For the purpose of our analysis, we use only the West German part of the German FFS. To include data from eastern Germany would have expanded the analysis to a three-country comparison for the time preceding 1990. Such an analysis is beyond the scope of this paper.

\section{Fertility Trends in Norway and West Germany}

Over the past decades, Norway and West Germany have displayed different fertility developments. Completed fertility has decreased in both countries, but West German women have a fertility level that is permanently lower in all birth cohorts compared to Norwegian females (Figure 1). The difference in the Completed Fertility Rate (CFR) between the two countries varies between 0.3 and 0.5 children per woman and cohort. It is interesting, too, that West-German women born after 1938 had on average less than 2.1 children, while their Norwegian counterparts still have a completed fertility of 2.1 .

[FIGURE 1 - ABOUT HERE]

Figures 2 and 3 display the parity distribution of West German and Norwegian women from various birth cohorts. Here again, we observe a substantial difference between the two countries. Among Norwegian women born before the end of World War II, mothers of three or more children outnumbered those with two children. In the oldest Norwegian cohort (1940), nearly half of the women have at least three children (46 percent). Women born in the 1950s tend towards the two-child norm / model. Around 40 percent of all women have two children and less than a third has three or 
more children. The pattern differs substantially from that of West Germany. West German women born after 1945 remain childless more often than do Norwegian women, and on the whole they tend to have smaller families, too. Among the cohorts born since 1945, women with one or two children clearly outnumber those with three or more children. As a consequence, the share of West German females with three or more children is considerably lower than in Norway, ranging from 27 percent among women born in 1940 to 18 percent among their female counterparts born in 1960. This compares to 46 percent among Norwegian women born in 1940 to 35 percent among Norwegian women born in 1960. Thus, West German women are less likely than Norwegian females to have a third child.

[FIGURE 2 AND FIGURE 3 - ABOUT HERE]

\section{Welfare State Regimes}

Comparative welfare-state research classifies West Germany and Norway into two different types of welfare states (Esping-Andersen 1990; 1999). The two states' approach to family, women, and fertility matters differs markedly. To gain a deeper understanding of the classification of the two countries, we first elaborate on two main concepts of Esping-Andersen's (1990) welfare state typology, namely demodification and de-familialization. (1.) De-commodification implies that the individual and his or her social or welfare claims are not dependent on the market. Services are rendered as a matter of right, so that a person can maintain a livelihood without reliance on the market. (2.) The concept of de-familialization describes a situation in which the individual is independent of its family status concerning social 
and material security. Welfare is provided from outside the family, either by the market or by the welfare state.

The Norwegian welfare state displays a relatively high degree of decommodification and de-familialization (Esping-Andersen 1990) at least since the beginning of the 1980s. The main characteristics of the state-funded Norwegian welfare system are a universalistic social-insurance and institutional-care system, support of female employment, a parental-leave system that includes high income compensation during times of employment interruptions, and - as a consequence of the institutional care system - a high coverage of childcare (Lödemel, Dahl, and Dröpping 2001; Neyer 2003). Although paid leave is granted in Norway since 1956 (by the National Insurance Act) and non-employed women are included through lump sum payments, parental leave and childcare policies in Norway lagged behind the policies of most other Nordic countries. Since 1977 and especially in the end of the 1980s, there have been a large number of improvements, including extensions of the leave period resulting in a maximum leave of 52 weeks in 1993. In parallel to these developments, job guarantee during leave was extended to 1 year and subsidized daycare expanded rapidly, in particular in the 1980s and 1990s, so that even day-care coverage for very young children (ages one to two years) is quite high (Rönsen 2004). These policies aim at assuring individual autonomy, the reconciliation of parenthood with female labor-force participation, and gender equality.

West Germany represents a "conservative" type of welfare state, characterized by a relatively weak degree of de-commodification and de-familialization (EspingAndersen 1990; 1999). The social-insurance system is oriented towards statusmaintenance and access to social insurance is based on employment and/or marriage. In contrast to the Norwegian welfare-state setup, the German welfare state thus 
provides social support in a very select way. Germany's family policies aim at protecting the traditional family, consisting of a male-breadwinner and a wife who is not employed or works on a part-time basis (Esping-Andersen 1999; Kreyenfeld 2002). Parental leave is comparatively long and benefits are means-tested, providing an income compensation that is relatively small. Childcare coverage is low and mostly provided on a part-time basis only (Hank and Kreyenfeld 2000; Neyer 2003). The main developments in the study period in West German family policies are the expansion of the kindergarten care system in the 1960s and 1970s. Kindergarten coverage with available places increased from 35 percent in 1965 to over 80 percent at the end of the 1980s. Nevertheless, only half-day-care was and still is provided. Nurseries and after-school-care still are only available for a minority of West German women (Kreyenfeld, Spieß, and Wagner 2002).

Various studies discuss the impact of these different family and social policy regimes on birth dynamics and behavior, even though the relation is a very complex one (Rönsen 2004). International comparative analyses with aggregate data (Gauthier and Hatzius 1997) find a slightly positive effect of child benefits on fertility outcome, for example. Furthermore, individual level analyses stress the impact of family policies on the speed of subsequent births (Olah 1996; Berinde 1999). With respect to the differences between the West German and Norwegian social and family policies settings mentioned above, we expect that any observed differences in third-birth patterns can be linked at least in part to the setup of the welfare regime. 


\section{Previous studies}

Third births in Scandinavia and West Germany have been analyzed before, but so far there has been no study comparing third-birth dynamics in Norway and West Germany. For single country studies or relevant comparative studies of other countries, see, for example: Kravdal (1990; 2002), Hoem and Hoem (1989), B. Hoem (1996), Berinde (1999), Corman (2000) for Scandinavia; Huinink (1988) for West Germany; and Hoem, Prskawetz and Neyer (2001) for Austria. The studies' empirical findings offer a valuable starting point for our working hypotheses (Note 1). The following hypotheses can be roughly grouped into three parts: 1. Demographic determinants, that is, the importance of age and timing; 2. socio-psychological determinants and family composition; 3 . socio-economic and welfare determinants.

1. Demographic determinants: Demographic studies have shown a positive impact of early first birth on subsequent fertility (Berinde 1999; Bumpass, Rindfuss, and Janosik 1978; Hoem 1996; Huinink 1988; Kravdal 1990; Morgan and Rindfuss 1999). Furthermore, an early start to family career is often interpreted as a sign of having high family values (Hoem, Prskawetz, and Neyer 2001; Huinink 1988; 1995). These arguments can as well be applied to the effects of spacing between the first two births. In most studies on the subject, shorter childbearing intervals are positively related to third births. The higher "speed" of births is often treated as an indication of relatively strong family intentions (Berinde 1999; Huinink 1988; Kravdal 1990). This effect has a mainly "mechanical" demographic side to it, that is, when a woman starts her childbearing relatively early it is easier to continue later on. It can be desirable to keep the birth intervals short (Friedman, Hechter, and Kanazawa 1994; Hoffman and Hoffman 1973; Huinink 1995) also in the light of various family-composition effects (e.g. interaction between family members). From an economic view it may be 
desirable to reduce opportunity costs arising from intervals between births and compatibility problems between labor and child rearing if one opts to have more children (Becker 1993; Gustafsson 1991; Ott 1998; 2001).

2. Socio-psychological determinants: Referring to socio-psychological approaches that point out the importance of family composition, interaction between the family members, and the resulting emotional benefits (e.g. from having a child of each sex) (Hoffman and Hoffman 1973), it can be argued that if the first two children are of the same sex (two girls or two boys), then the risk for a third birth increases, with the aim to achieve a more balanced sex ratio in the family (Andersson et al. 2004).

Previous studies have shown that the family background (the area of socialization, the number of siblings etc.) have an impact on fertility behavior in Germany (Huinink 1988; Sieder 1991) and in Norway (Kravdal 1990; 2002). The higher the number of siblings one has, the higher is the risk that a woman desires to have a large family. Other studies also have shown that socialization within a rural area usually positively affects third-birth probabilities.

Studies on union commitment, step families, and couple utility of children reveal a strong influence of union dynamics on fertility behavior (Hoffman and Hoffman 1973; Thomson 1983; 1997; Thomson, Hanson, and McLanahan 1994; Prskawetz et al. 2003). These approaches point out that fertility increases after re-marriage or after new partnership formation and argue that third-birth patterns to a large extent are related to stepfamily fertility.

3. Socio-economic and welfare determinants: Economic approaches (Becker 1993; Gustafsson 1991) tend to assume a negative impact of high education on women's fertility. However, many studies have shown that this assumption is not a straightforward one, especially when we look at higher-parity risks (Berinde 1999; 
Corman 2000; Hoem and Hoem 1989; Hoem, Prskawetz, and Neyer 2001; Huinink 1988; Kravdal 1990; 2001). Furthermore, the link between education and fertility is often discussed in the light of various family-policy settings in different welfare-state regimes, these policies are able to reduce opportunity costs and compatibility problems (Gauthier 2001; Kreyenfeld 2002; Neyer 2003; Rönsen and Sundström 1999; Kravdal 1990; Kravdal 2001). We stated above that Norway and West Germany stand for two different kinds of welfare regimes and levels of de-commodification and de-familialization (parental leave regulations, child care supply, social insurance and family support system) (Esping-Andersen 1999). Some authors argue that Norwegian family policy reduces women's opportunity costs by means of providing day care and parental leave etc, thus facilitating the realization of the desire to have relatively large families (more than two children) and this way weakening the compatibility issues (the latter which may lead to a reduction in the fertility of highly educated women in particular).

The German case is more complex. The low support provided by the German welfare-state system for work-oriented or employed mothers increases the opportunity costs arising from childbirth for these women. If we follow the economic assumption that women of relatively low education have lower opportunity costs than their higher educated counterparts, one would expect third-birth risks to decline with an increasing educational level. A previous study does not support this assumption, however: Huinink (1988) did not find any significant educational effects in cohorts with completed fertility among German mothers.

Based on very similar arguments regarding the link between education and fertility, economic approaches (Becker 1993; Gustafsson 1991) assume female labor-force participation to have a negative impact on fertility. Adherents to these approaches 
mainly give attention to compatibility problems and opportunity costs during child rearing in terms of potential or expected income (Ott 1998; 2001). Policy-directed fertility studies, however, indicate that appropriate family support and policies are able to reduce the negative externalities of labor on fertility (Gauthier 2001; Kreyenfeld 2002; Neyer 2003; Rönsen and Sundström 1999; Rönsen 2004; Berinde 1999; Corman 2000; Hoem and Hoem 1989; Hoem, Prskawetz, and Neyer 2001).

Concerning the possible similarities between Norwegian and West German women in third birth dynamics, we argue that stepfamily and union commitment approaches may make an important contribution towards explaining third birth behavior in both countries. We further expect the effect of many demographic, socio-psychological, and socio-demographic characteristics to be similar in both countries reflecting the fact that cultural differences are relatively small because both belong to the group of industrialized western European countries. Differences in third-birth dynamics are mainly expected to be related to the impact of socio-economic factors.

\section{Empirical Analysis}

\subsection{Data - The German and Norwegian FFS}

Our study is based on the "Fertility and Family Survey" (FFS). The Norwegian data was collected in 1988 and include 4933 women of the birth cohorts 1945, 1950, 1955, 1960, and 1965. Men were interviewed, too (1974 of the birth cohort 1945 and $1960)$ but we restrict our analysis to women. The German FFS was collected in 1992. Since East- and West Germany were separate countries until 1990, we only use the 
West German part of the FFS. It covers women and men from the 1952 - 1972 birth cohorts and we will use only the data on the female respondents.

Table 1 provides an overview of the cases included and omitted in the West German and Norwegian FFS. For the empirical study, we look at 1691 Norwegian two-child mothers aged 24-43 who have given a total of 586 third births and at 716 German two-child mothers aged 20-39, with a third-birth total of 186 . Due to the fact the West German FFS included women aged 20 - 39 (compared to ages 23-43 as to the Norwegian sample), West German two-child mothers are relatively young and potentially a more selective group.

[TABLE 1 - ABOUT HERE]

We calculate third conception risks for Norwegian and German two-child-mothers using piece-wise constant regression with the basic time factor defined as a categorical variable. The process time is the age of the second child or, more correctly, duration since second birth. The process ends at third conception. The time of conception is backdated to seven months before birth. Cases are censored seven months preceding the date of interview. The piece-wise constant model can be written as:

$$
\mu(t)_{i j k l m o p q r s}=a_{i}(t) * b_{j} * c_{k} * d_{l} * e_{m} * g_{o} * h_{p} * i_{q} * j_{r}(t) * k_{s}(t)
$$

$\mu(t)_{i j k l m o p q r s}$ is equivalent to the intensity of third conception (assumingly 7 months before birth (see Note 2)), which is affected by time factor $a_{i}(t)$ (duration since second birth); the time constant covariates are as follows: 


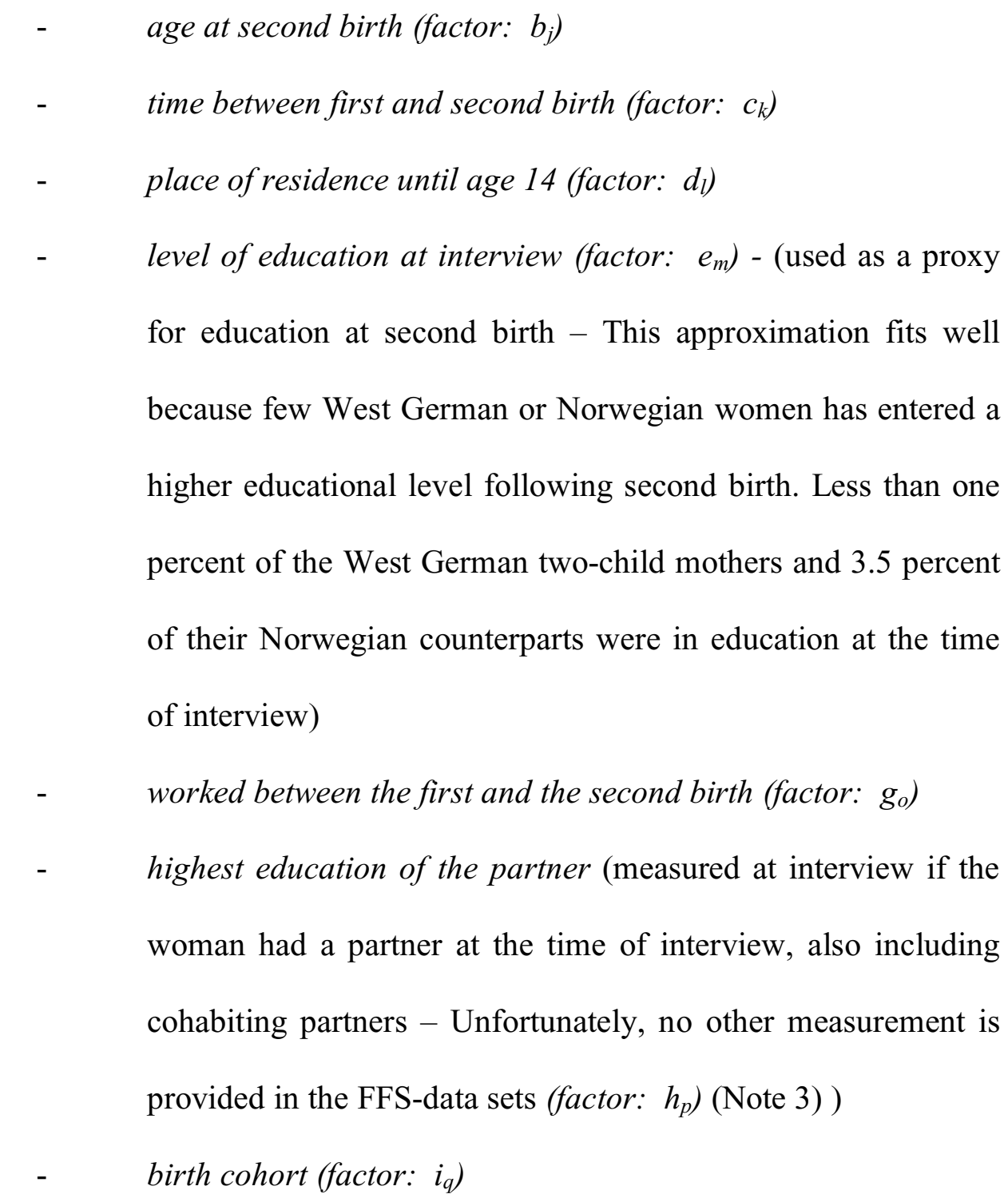

and the time varying covariates:
- $\quad$ employment status after second birth (factor: $\left.j_{r}(t)\right)$
- $\quad$ family status after second birth (factor: $\left.k_{s}(t)\right)$.

Table 2 lists the distribution of two-child mothers over all variables for Norway and West Germany. In general, Norwegian mothers of two children had their first child slightly earlier than the corresponding mothers in West Germany. Of the Norwegian sample, 76 percent females gave first childbirth by age 25 compared to 66 percent of the West German two-child mothers. The difference in the time span 
between the first and second child is very small. A large gap between Norway and West Germany is observed when allocating two-child mothers to urban and rural regions of their childhood. The measure used to divide the region into rural and urban areas is the same for both countries: rural $=$ smaller than 2000 inhabitants; urban $=$ over 2000 inhabitants.

The educational variable used is coded in three categories: "low" for primary educational attainment, "middle" for secondary education, and "high" for university or similar education. The levels of the educational variables (for the respondent and the partner) are not really the same for Norway and West Germany as the education system differs between the two countries. The West German basic school system is split into "Hauptschule" (up to age 16), "Realschule" (up to age 17) and "Gymnasium" (up to age 20). German pupils decide at an early age which of these lines to take. Norway has a school system that is comprehensive up to age 17.

\section{[TABLE 2 - ABOUT HERE]}

In general, Norwegian mothers of two children have a lower educational attainment than their West German counterparts, which is mainly due to the comprehensive school system in Norway. The largest part of Norwegian mothers at least has an intermediate education, whereas the majority of German two-child mothers are educated to a comparatively lower standard.

Only very few West German two-child mothers were employed between first and second birth (below three percent). In Norway, every fifth mother worked during this time. This indicates some differences between Norway and West Germany in the opportunity to combine work with motherhood. 
Finally, changes in the family and employment status starting from second birth will be modeled with time since second birth. The first covariate is split into four different levels: first marriage; second or higher-rate marriage; divorced or widowed; never married.

\subsection{Analyses and Results}

Tables 3 and 4 give the results of our intensity regression analysis for West Germany and Norway, respectively. We used stepwise modeling in order to account for inter-variable effects. Nevertheless, we tried to group the variables according to th

$1^{s t}$ model: The first model includes the baseline intensity (age of second child) and four fixed covariates. These are mainly socio-demographic and social-background variables. The highest propensity of third conception occurs between two and four years after second birth. This pattern is the same for Norway and West Germany and also holds when further covariates are added. But the Norwegian time frame for third conception seems to be broader than for West Germany. Age at first birth has a similar effect in Norway and West Germany, but it is significant only for Norwegian two-child mothers. Women who were young at first birth (between 14 and 19 years) have the highest risks of third conception. The risk declines in both countries when women bear their first child later in life.

In Model 1 for West Germany, only the baseline intensity and the time span between the first and second child shows a significant effect on third conception (possibly because the data set for Germany is small). The shorter the birth interval is, 
the larger is the probability of third conception. For Norwegian two-child-mothers, the effects are much sharper than in West Germany.

There are no significant effects of the gender of the first two children in West Germany. But the risks indicate that third childbirth is more likely if the first two children are either two boys or two girls. This effect is significant for Norway. There is another gender effect, too: Norwegian mothers of two boys seem to have a higher propensity of third conception than mothers of two girls.

The last variable in Model 1 denotes the size of residence up to age 15 . We achieve clear results for Norwegian two-child mothers. Mothers who have grown up in mainly rural regions show a much higher third conception risk, by around one third, compared to their "urban" counterparts. In West Germany, the effect is the opposite but it is not significant.

$2^{\text {nd }}$ model: The second model also includes the highest educational attainment of two-child mothers. There is a strong positive effect of the highest educational level in West Germany and a less strong effect for the lowest level compared to the intermediate category. This means that highly educated as well as lowly educated two-child mothers in West Germany have the highest inclination to third conception. In Norway, a slight U-shape can be observed but the effects are much weaker.

$3^{r d}$ model: The third model adds a time fixed and a time-varying covariate for the measurement of the employment status. The Norwegian sample reveals no significant effects. The patterns are different for West Germany, however. We get a significant negative effect for employed mothers. Furthermore, we observe the positive (but not significant) effect of belonging to the dominating group of mothers who "never worked between the first two births" on third-conception risk. 
$4^{\text {th }}$ model: Next, the highest educational attainment of the partner is introduced to the analyses. The education of the partner shows an effect on third-conception risks in Norway and in West Germany that is in part significant. A highly educated (coresiding) partner increases the propensity of a third conception of their female partner in both countries. This effect is stronger in West Germany than it is in Norway. In general, the partner effect has a slight J-shape in both countries.

[TABLE 3 AND TABLE 4 - ABOUT HERE]

Note that the importance of the effect of the mother's high educational attainment decreases in both countries when we control also for the characteristics of the male partner.

$5^{\text {th }}$ model: The fifth model is calculated by including the time varying covariate of the family status after second birth. There is a strong positive effect on third conception for remarried two-child-mothers in Norway as well as in West Germany.

$6^{\text {th }}$ model: The birth cohort is introduced last. For Norwegian two-child mothers there is nearly no effect of this variable whereas in West Germany, the cohort effect is significant. The younger cohorts have a higher intensity of third conception. The cohort pattern in West Germany is quite surprising, because estimations by Kreyenfeld (2002) and Dorbritz and Schwarz (1996) do not show such an effect. The differences in the results possibly have arisen because of the small number of twochild mothers in the younger cohorts. 


\subsubsection{Introducing a new marriage variable}

As we have seen in Tables 3 and 4, the variable that measures the marital status after second birth seems to be very important in West Germany as well as in Norway. For re-married women, the risk for third conception is higher than in every other category (first marriage, divorced or widowed, never married). These patterns can be interpreted as the effects of step-family fertility.

Studies of stepfamily fertility have shown (Thomson, Hanson, and McLanahan 1994; Thomson 1997; Vikat, Thomson, and Hoem 1997) that remarried and repartnered couples have higher conception risks because they want to demonstrate commitment to the new union or because they desire to have a sibling for their previous common child. To account explicitly for the effects of changing or not changing the marital status, we construct a new and more detailed marital status variable.

It is generated as an interaction variable between marital status at second birth and the time-varying covariate for marital status after second birth. Collapsing and deleting some categories, we get the following time-varying variable:

Marital status since second birth:

$$
\begin{array}{ll}
\text { - never married } & \left(\text { since } 2^{\text {nd }} \text { birth }\right) \\
\text { - first marriage } & \left(\text { since } 2^{\text {nd }} \text { birth }\right) \\
\text { - marriage of second or higher order } & \left(\text { since } 2^{\text {nd }} \text { birth }\right) \\
\text { - divorced or widowed } & \text { (since } \left.2^{\text {nd }} \text { birth }\right) \\
\text { - newly first married } & \left(\text { after } 2^{\text {nd }} \text { birth }\right) \\
\text { - newly re-married } & \left(\text { after } 2^{\text {nd }} \text { birth }\right) \\
\text { - newly divorced or widowed } & \text { (after } \left.2^{\text {nd }} \text { birth }\right)
\end{array}
$$


[TABLE 5 - ABOUT HERE]

The relative risks of third conception based on the new variable show the patterns already discovered (see Tables 3 and 4) to more detail (see Table 6).

In West Germany, two-child mothers who married after second birth show fairly equal patterns of third conception regardless of marital order. For them, the risk is more than three times higher than for two-child mothers remaining in first marriage. For Norway, re-married two-child mothers have the highest risk of becoming a threechild mother regardless of whether they re-married before or after second birth. Furthermore, the group of never married West German two-child mothers shows elevated risks of third conception. Divorce (or widowhood) seems to exert a positive influence on the probability of third conception in West Germany. Nevertheless, both countries show similar patterns in the main impacts of stepfamily fertility.

[TABLE 6 - ABOUT HERE]

\subsection{Interpretation}

1. Demographic determinants: It seems that our empirical findings support our assumptions concerning age at first birth and spacing in-between first and second birth. Firstly, we discover no substantial differences between Norway and West Germany when it comes to age and timing determinants. Secondly, we interpret the effects in both countries as an indication of the high family building intentions of these women. We assume that women who desire to have relatively large families try to start their fertility career earlier and bear children at higher speed. Taking another 
perspective, intentions, attitudes, and work or educational options may change after early first childbirth, so that women become more likely to have additional children and a larger family. Thirdly, starting early and having children within a short period of time reduces the period of childrearing and of career interruption at "mid-point". This reduces opportunity costs, such as loss of potential income, loss of knowledge gained through work experience and reduced employment opportunities.

2. Socio-psychological determinants and marital status: Our empirical findings on the sex of the first and second child, the marital status, and the area of upbringing to age 15 mainly confirm previous findings. As to the impact of sex composition, having at least one child of each sex is likely to increase the emotional benefits for both partners. Emotional benefits are seen here to include psychological wellbeing from interaction and communication with the children: A balanced sex composition may prevent the father or mother from the feeling to be underrepresented in the family in terms of gender.

In addition, we find a strong positive impact of re-marriage on third-birth risks. It turns out that new partnership formation increases the propensity of third childbirth and it is one of the most important factors in the models for West Germany and Norway. As do other authors, we see this mainly in the light of the sociopsychological aspects to it. The realization of a common child during a newly formed marriage when the woman has two children already seems to provide stability and union commitment for the wife and husband. In this sense, an additional child may increase the sum of socio-psychological benefits for the couple. We interpret the additional positive effect among never married women in West Germany, as a selection effect of long-term cohabiting two-child mothers. 
3. Socio-economic and welfare determinants: We attribute the weak educational effects in Norway to the Norwegian universalistic family policies, which are independent of social class or marital status, providing relatively high childcare coverage and high income compensation during parental leave. These policy settings reduce the indirect and direct costs of having children for all work-orientated women, regardless of their educational level.

The strong educational gradients in West Germany have to be interpreted in the light of the conservative welfare-state regime and the resulting different direct and indirect costs for different social groups (low coverage of childcare and care that is available on a part-time basis only, long parental leave, low and means-tested parental-leave benefits, male-breadwinner taxation). The positive impact of high education weakens when we control for the education of the male partner. This may be an indication that women with higher education tend to stay at home to look after their children when the partner's income is sufficient to sustain the family. The positive effects of non-employment after second childbirth and of not having worked between first and second childbirth support this view. Further, we assume that high education does not necessarily mean lower family values, because: 1. Higher education usually indicates greater individual autonomy. The latter does not inevitably imply to have fewer children, it may just mean to have the number of children one desires to have - irrespective of social norms. Highly educated women may also live in households in which parenting and household duties are either shared more equally between the partners or in which (paid) household and care assistance reduces the household burden on women. 2. Highly educated women with two children are a very select group. They probably already found a way of handling the compatibility 
problems and opportunity cost arising from having children so that an additional child is not that "expensive" or "problematic".

From a purely neo-classical economic view, the weakly positive effect of lowly educated women can be interpreted as an effect of lower opportunity costs when raising children (Becker 1993). But we can also assume that women of relatively low education have other life plans and other expectations than other women, and this may be conducive to having larger families.

Finally, our findings support our assumptions on female labor-force participation. There is hardly any effect of women's labor-force participation in Norway, this in contrast to the negative effect we find for West Germany. Again, this can be attributed to the different welfare-state settings that the two countries have. The Norwegian family policies facilitate the combination of parenthood and work, whereas WestGerman policies do not support mother's employment, but instead motivate women to stay at home to look after their children.

\section{Concluding remarks}

Our event-history analyses of third-birth patterns of women in West Germany and Norway yield a number of new insights into third-birth dynamics in general while at the same time confirming several previous findings on such dynamics. It appears that the impact of different demographic factors is very similar across the two countries. This holds for variables related to age and timing of previous births, as well as for marital status. The marriage behavior of the mother before and after second birth is probably the strongest factor of influence and one of the main driving forces behind third-birth dynamics in the two countries. Differences in third-birth behavior between 
West German and Norwegian women are primarily connected to socio-economic determinants. We ascribe these differences to differences in the German and Scandinavian welfare-regimes and family policies in that they lend support to different types of activities of women, mothers, and families. Socio-economic differences in childbearing are weak in the universalistic welfare state, and more pronounced in the "conservative" welfare state.

\section{Acknowledgments}

I am grateful for valuable comments and advice from Gerda Neyer, Gunnar Andersson, Elizabeth Thomson, Lisbeth Knudson, Annemette Lindhardt Olsen, and the anonymous reviewers of this article. I am very thankful for language editing by Susann Backer, too. Furthermore, I would like to thank Maggie Kulik and Michaela Kreyenfeld and all other friends and colleges at the Max Planck Institute for Demographic Research for their support. 


\section{Notes:}

Note 1: For a more detailed discussion of the theoretical approaches and studies on third-birth behavior and the deducted hypotheses, see Alich (2004) "Das dritte Kind Ein Vergleich zwischen Deutschland und Norwegen".

Note 2: In order to account for the fact that a women is probably not aware at the time of conception that she is pregnant ( 9 months before the birth), we choose seven months as the starting point of the analyzed process.

Note 3: This variable is a little bit more problematic since no data on the education of the previous partners are available. Thus no partner data is available if a couple splits up and the two-child mother lives alone at the time of interview.

\section{References:}

Alich, David (2004). Das dritte Kind - Ein Vergleich zwischen Deutschland und Norwegen. [The Third Child - A Comparision between Germany and Norway]. Rostock: Universität Rostock.

Andersson, Gunnar, Karsten Hank, Marit Rönsen (2004). Gendering the Family Composition: Sex Preferences for Children and Childbearing Behaviour in the Nordic Countries. MPIDR Working Papers; WP-2004-019.

Becker, Gary S (1993). A Treatise on the Family. Havard: Havard University Press. 
Berinde, Diana (1999). Pathways to a Third Child in Sweden. European Journal of Population 1999; 4: 349-78.

Bumpass, Larry L., Ronald R. Rindfuss, Richard B. Janosik (1978). Age and Marital Status at First Birth and the Pace of Subsequent Fertility. Demography 1978; 15 (1): 75-86.

Corman, Diana (2000). Family Policy, Working Life, and the Third Birth in Contemporary France and Sweden. Stockholm: Licentiatavhandling.

Dorbritz, Jürgen, Karl Schwarz (1996). Kinderlosigkeit in Deutschland - ein Massenphänomen: Analysen zu Erscheinungsformen und Ursachen. [Childlessness in Germany - A Mass Phenomena: Analyses of Types and Causes]. Zeitschrift Für Bevölkerungswissenschaft 1996; 21: 231-61.

Engstler, Heribert, Sonja Menning (2003). Die Familie im Spiegel der amtlichen Statistik. Lebensformen, Familienstrukturen, wirtschaftliche Situation der Familien und familiendemographische Entwicklung in Deutschland. [The Family at a Glance in Public Statistics. Life Forms, Family Structures, Economic Situation of Families and Family Demographic Developments in Germany]. Berlin: Bundesministerium für Familie, Senioren Frauen und Jugend and Statistisches Bundesamt.

Esping-Andersen, Gøsta (1990). The Three Worlds of Welfare Capitalism. Cambridge: Polity Press.

Esping-Andersen, Gøsta (1999). Social Foundations of Postindustrial Economies. New York: Oxford University Press. 
Friedman, Debra, Michael Hechter, Satoshi Kanazawa (1994). A Theory of the Value of Children. Demography 1994; 31 (3): 375-104.

Gauthier, Anne H. (2001). The Impact of Public Policies on Families and Demographic Behavior. Paper at the ESF/EURESCO Conference: The Second Demographic Transition in Europe.

Gauthier, Anne H., J. Hatzius (1997). Family Benefits and Fertility: An Econometric Analysis. Population Studies 1997; 51: 295-306.

Gustafsson, Siv (1991). Neoklassische ökonomische Theorien und die Lage der Frau: Ansätze und Ergebnisse zu Arbeitsmarkt, Haushalt und der Geburt von Kindern. [Neoclassical Economic Theories and the Situation of Women: Approaches and Results Concerning Labor Force, Household and Childbearing.] In: Karl Ulrich Mayer, Jutta Allmendinger, Johannes Huinink, editors. Vom Regen in die Traufe: Frauen zwischen Arbeit und Familie. Frankfurt/New York: Campus Verlag.

Hank, Karsten, Michaela Kreyenfeld (2000). Does the Availability of Childcare Influence the Employment of Mothers? MPIDR Working Papers; WP2000-003.

Hoem, Britta (1996). The Social Meaning of the Age at Second Birth for Third-Birth Fertility: A Methodological Note on the Need to Sometimes Respecify an Intermediate Variable. Yearbook of Population Research in Finland 1996; 33: 333-39.

Hoem, Britta , and Jan M. Hoem (1989). The Impact of Women's Employment on Second and Third Births in Modern Sweden. Population Studies 1989; 
43: 47-67.

Hoem, Jan M., Alexia Prskawetz, Gerda Neyer (2001). Antonomy or Conserative Adjustment? The Effect of Public Policies and Educational Attainment on Third Births in Austria. MPIDR Working Papers; WP-2001-016.

Hoffman, Lois Wladis, and Martin L. Hoffman (1973). The Value of Children to Parents. In: J. T. Fawcett, editor. Psychological Perspektives on Population. New York: Basic Books: 19-76.

Huinink, Johannes (1988). Das zweite und das dritte Kind: Sind wir auf dem Weg zur Ein-Kind-Familie?. [The Second and the Third Child: Are We on the Way towards the One-Child Family?]. Frankfurt a.M.: Universität Frankfurt.

Huinink, Johannes (1995). Warum noch Familie? Zur Attraktivität von Partnerschaft und Elternschaft in unserer Gesellschaft. [Why still Family? The Attraction of Partnership and Parenthood in Our Society]. Frankfurt a. M.: Campus Verlag.

Kravdal, Øystein (1990). Who Has a Third Child in Contemporary Norway?: A Register-based Examination of Sociodemographic Determinants. Rapporter Fra Statistisk Sentralbyra.

Kravdal, Øystein (2001). The High Fertility of College Educated Women in Norway: An Artefact of the Seperate Modelling of Each Parity Transition. Demographic Research 2001; 5: 188-214.

Kravdal, Øystein (2002). Is the Previously Reported Increase in Second- and Higher- 
order Birth Rates in Norway and Sweden from the Mid-1970s Real or a Result of Inadequate Estimation Methods? Demographic Research 2002; 6: $242-62$.

Kreyenfeld, Michaela (2002). Time-squeeze, Partner Effect or Selfselection? An Investigation into the Positive Effect of Women's Education on Second Birth Risks in West Germany. Demographic Research 2002; 7: 16-41.

Kreyenfeld, Michaela, C. K. Spieß, G. G. Wagner (2002). Kinderbetreuungspolitik in Deutschland - Möglichkeiten nachfrageorientierter Steuerungs- und Finanzierungsinstrumente. [Child Care Policy in Germany - Possibilities of Demand-Oriented Governance- and Financing Instruments]. Zeitschrift für Erziehungswissenschaft 2002; 5 (2): 201-221.

Lødemel, Ivar, Espen Dahl, and Jon Anders Drøpping (2001). Social Policies in Norway: Processes, Structures and Implementation Mechanisms. New York: United Nations.

Morgan, P. S., Ronald S. Rindfuss (1999). Reexamining the Link of Early Childbearing to Marriage and to Subsequent Fertility. Demography 1999; 36 (1): 59-76.

Neyer, Gerda (2003). Family Policies and Low Fertility in Western Europe. MPIDR Working Papers; WP-2003-021.

OECD - Organization for Economic Cooperation and Development (1997). Thematic Review of the First Years of Tertiary Education - Country Note: Norway. OECD Education Committess Thematic Review 1997: 1-19. 
Olah, Livia Sz (1996). The Impact of Public Policies on the Second-Birth Rates in Sweden: a Gender Perspective. Stockholm Research Reports in Demography.

Ott, Notburga (1998). Der familienökonomische Ansatz von Gary S. Becker. [The Family Economic Approach of Gary S. Becker]. In: Ingo Pies, Martin Leschke, editors. Gary Beckers Ökonomischer Imperialismus. Tübingen: Mohr Siebeck: 63-90.

Ott, Notburga (2001). Der Erklärungsansatz der Familienökonomik. [The Explanation Approach of the Family Economics]. In: Johannes Huinink, Klaus Peter Strohmeier, Michael Wagner, editors. Zum Stand Familiensoziologischer Theoriebildung. Würzburg: Ergonverlag: 129-43.

Prskawetz, Alexia, Andres Vikat, Dimiter Philipov, Henriette Engelhardt. (2003). Pathways to Stepfamily Formation in Europe: Results from the FFS. Demographic Research 2003; 8: 107-149.

Rønsen, Marit. (2004). Fertility and Family Policy in Norway - A Reflection on Trends and Possible Connections. Demographic Research 2004; 10 : 266-86.

Rønsen, Marit, and M. Sundstrøm (1999). Public Policies and the Employment Dynamics among New Mothers - A Comparision of Finland, Norway and Sweden. Discussion Papers No. 263, Statistics Norway.

Sieder, Reinhard (1991). Sozialgeschichte der Familie. [The Social History of the Family]. Frankfurt a.M.: Suhrkamp. 
Thomson, Elizabeth (1983). Individual and Couple Utility of Children. Demography 20, (4): 507-18.

Thomson, Elizabeth (1997). Her, His and Their Children: Influences on Couple Childbearing Decisions. NSFH Working Paper 1997; 76.

Thomson, Elizabeth, Thomas L. Hanson, Sara S. McLanahan. (1994). Family Structure and Child Well-Being: Economic Resources vs. Parental Behaviors. Social Forces 1994; 73 (1): 211-42.

Vikat, Andres, Elizabeth Thomson, Jan Hoem. (1997). Stepfamily Fertility in Contemporary Sweden: The Impact of Childbearing before the Current Union. Population Studies 1997; 53: 211-25. 


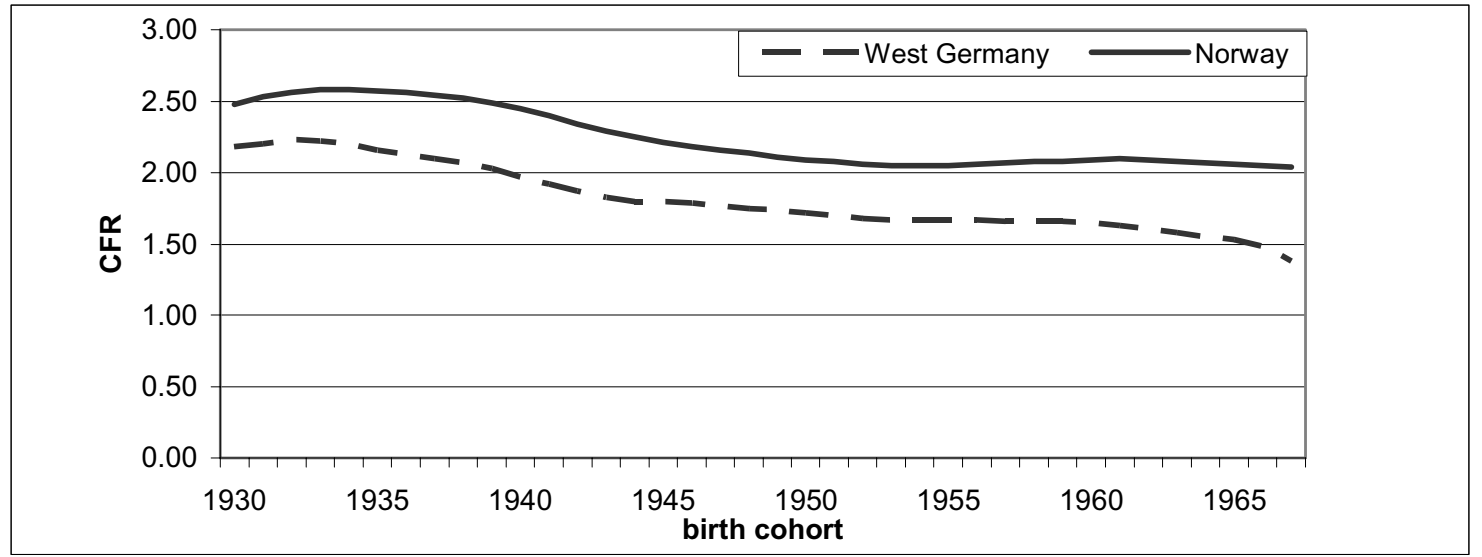

Figure 1: Norway and West Germany - Completed fertility rate (birth cohorts: 1930 to 1960), source: OECD - Demographic Year Book 2001 


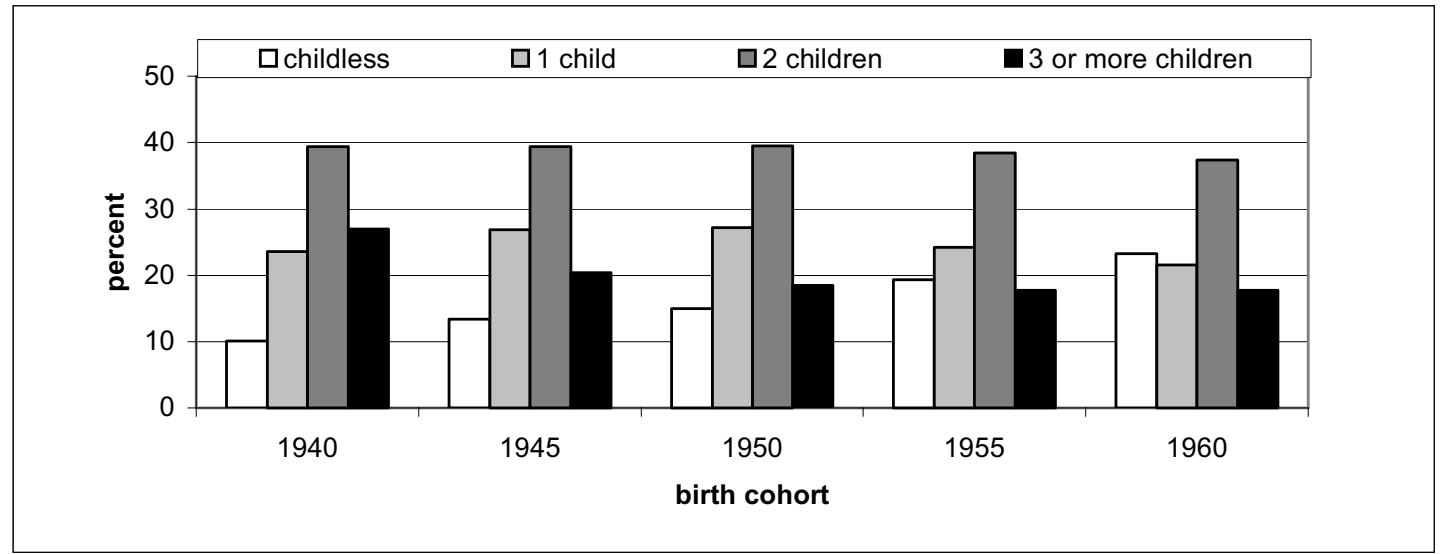

Figure 2: West Germany - Percentage of women by number of children (birth cohorts 1940 to 1960), source: The Family at a Glance of the Public Statistics - Engstler und Menning (2003) 


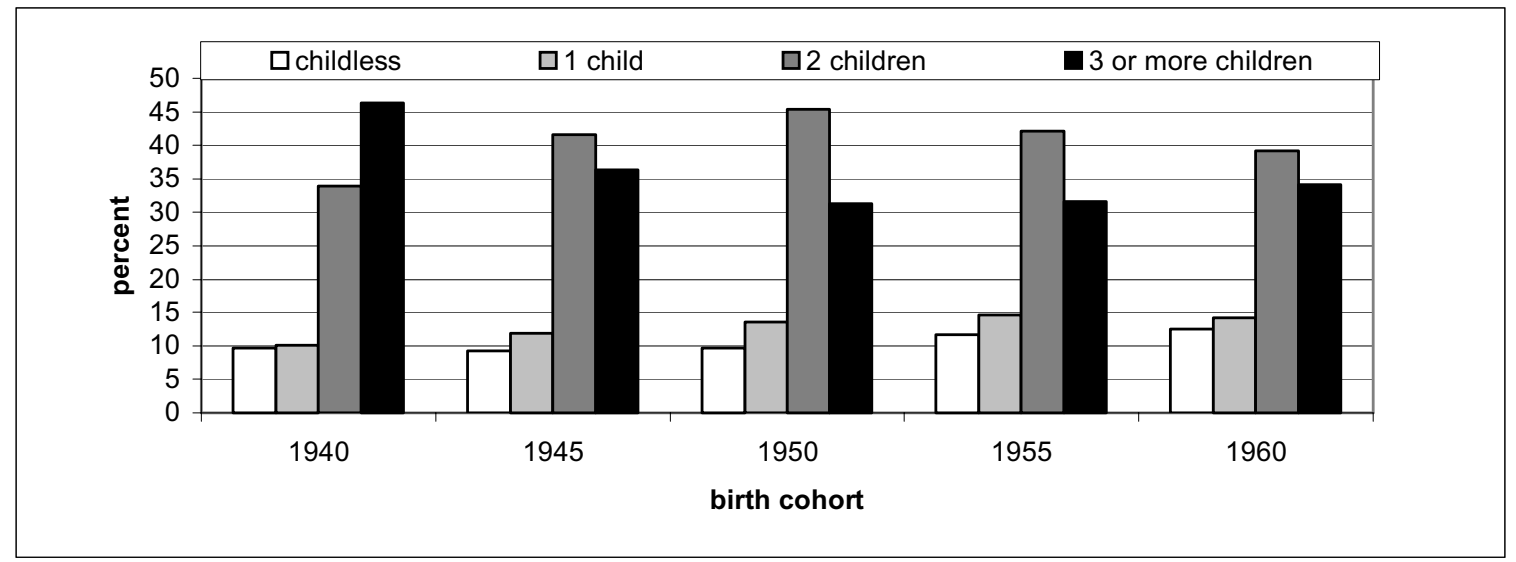

Figure 3: Norway - Percentage of women by number of children (birth cohorts 1940 to 1960), source: Population Statistics System, Statistics Norway (2004) 


\begin{tabular}{|c|c|c|c|c|}
\hline & \multicolumn{2}{|c|}{ NORWAY } & \multicolumn{2}{|c|}{ WEST GERMANY } \\
\hline $\begin{array}{l}\text { Number of women in the dataset } \\
\text {... women with children } \\
\text {... women with at least two children }\end{array}$ & $\begin{array}{l}4019 \\
2459 \\
1694\end{array}$ & $\begin{array}{r}100.0 \% \\
61.2 \% \\
42.1 \%\end{array}$ & $\begin{array}{c}3012 \\
1413 \\
758\end{array}$ & $\begin{array}{r}100.0 \% \\
46.9 \% \\
25.2 \%\end{array}$ \\
\hline $\begin{array}{l}\text { Omitted cases: } \\
\text { Twins by second birth } \\
\text { Third child is adopted / step / foster child } \\
\text { First birth before age } 14 \\
\text { First child died before second birth } \\
\text { Second child died before third birth }\end{array}$ & & & & \\
\hline $\begin{array}{l}\text { Omitted due to missing: } \\
\text { Date of birth second child } \\
\text { Date of birth third child } \\
\text { Birth cohort of the respondent }\end{array}$ & \multicolumn{2}{|c|}{$\begin{array}{l}0 \\
0 \\
0\end{array}$} & \multicolumn{2}{|c|}{$\begin{array}{c}20 \\
2 \\
1\end{array}$} \\
\hline Total number of omitted cases & \multicolumn{2}{|c|}{3} & \multicolumn{2}{|c|}{42} \\
\hline $\begin{array}{l}\text { Number of two-child mothers } \\
\text { Number of third births }\end{array}$ & $\begin{array}{c}1691 \\
586\end{array}$ & $\begin{array}{r}100.0 \% \\
34.7 \%\end{array}$ & $\begin{array}{l}716 \\
186\end{array}$ & $\begin{aligned} 100.0 \% \\
26.0 \%\end{aligned}$ \\
\hline
\end{tabular}

Table 1: Number of included and omitted cases in the Norwegian and German FFS-women 


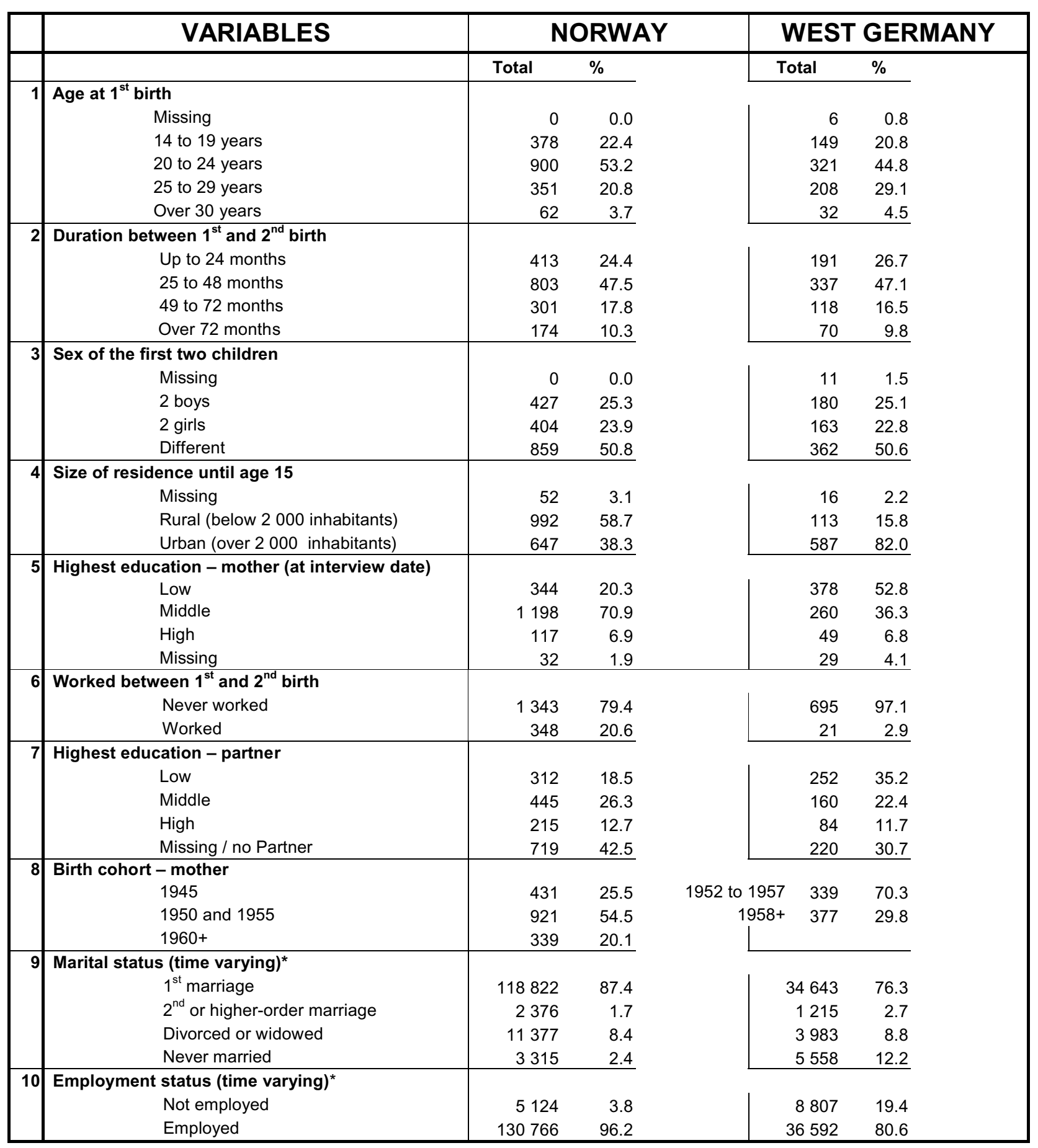

Table 2: Frequencies (total and percentages) of two-child mothers in the Norwegian and West German FFS

* The unit for these two variables is months of risk 


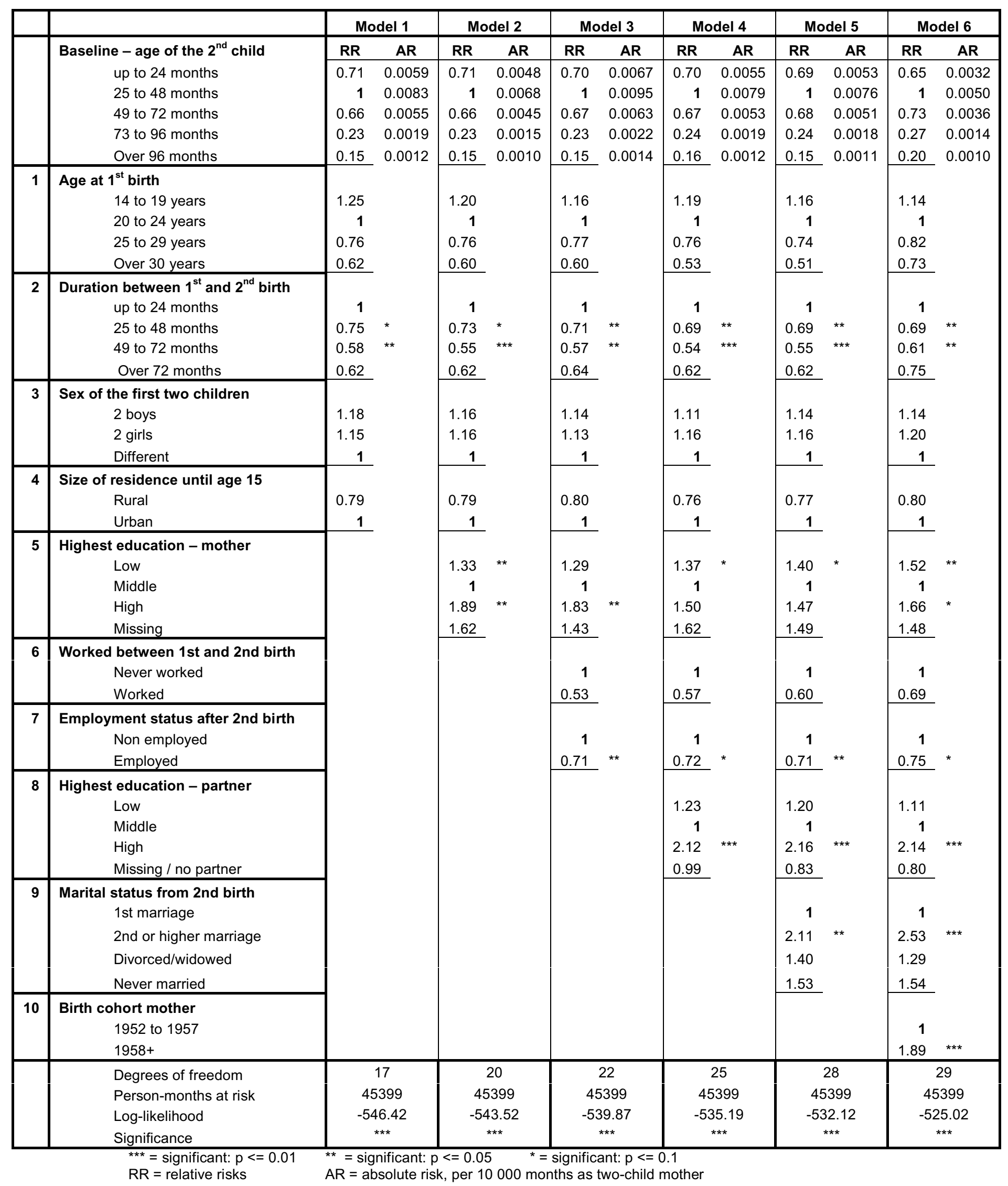

Table 3: West Germany - Relative risks of a third birth for two-child mothers (birth cohorts 1952 to 1972), hazard ratios; note: for the following covariates the models were also controlled for missing values: age at $1^{\text {st }}$ birth, sex of first 2 children, size of residence until age 15 


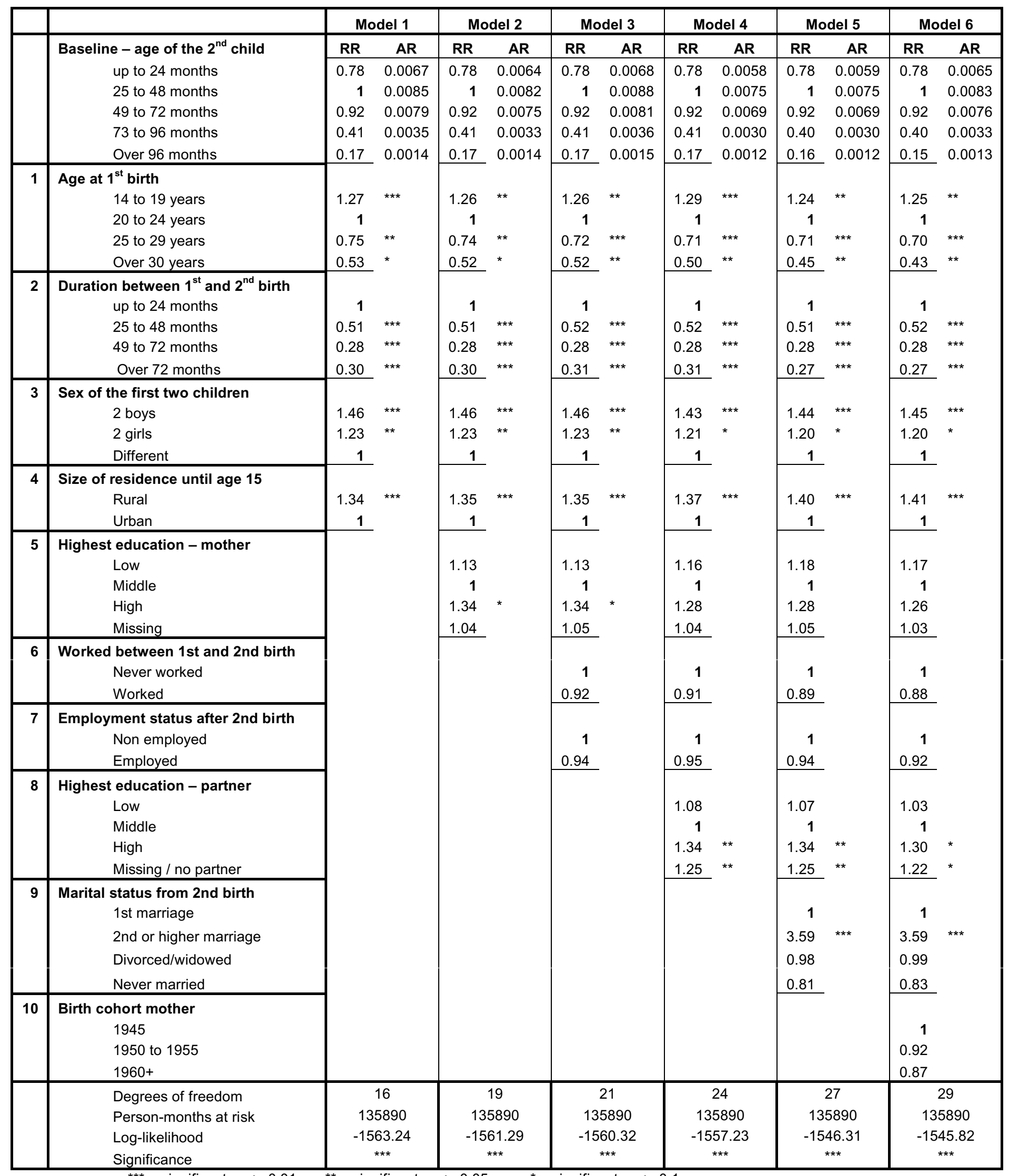

${ }^{* * *}=$ significant: $p<=0.01 \quad{ }^{* *}=$ significant: $p<=0.05 \quad{ }^{*}=$ significant: $p<=0.1$

$\mathrm{RR}=$ relative risks $\quad \mathrm{AR}=$ absolute risk, per 10000 months as two-child mother

Table 4: Norway - Relative risks of a third birth for two-child mothers (birth cohorts 1945, 1950,

1955, 1960, 1965 and 1968), hazard ratios; note: for the following covariates the models were also controlled for missing values: sex of first 2 children, size of residence until age 15 


\begin{tabular}{|l|r|r|r|r|r|r|}
\hline \multirow{2}{*}{ Marital status since $\mathbf{2}^{\text {nd }}$ birth } & \multicolumn{3}{|c|}{ NORWAY } & \multicolumn{3}{|c|}{ WEST GERMANY } \\
\cline { 2 - 6 } & \multicolumn{2}{|c|}{ Exposures } & Occurrences & \multicolumn{2}{|c|}{ Exposures } & Occurrences \\
\hline Never married & 3315 & 2.4 & 100 & 5558 & 12.2 & 110 \\
$\mathbf{1}^{\text {st }}$ marriage & 116811 & 86.0 & 1508 & 33684 & 74.2 & 542 \\
$\mathbf{2}^{\text {nd }}$ or higher-order marriage & 979 & 0.7 & 20 & 588 & 1.3 & 15 \\
Divorced or widowed & 2618 & 1.9 & 60 & 1800 & 4.0 & 44 \\
\hline Recently first married & 2011 & 1.5 & 29 & 959 & 2.1 & 14 \\
Recently remarried & 1397 & 1.0 & 31 & 627 & 1.4 & 10 \\
Recently divorced or widowed & 8759 & 6.4 & 151 & 2183 & 4.8 & 54 \\
\hline
\end{tabular}

Table 5: Occurrences and exposure-months (absolute values and percentages) of West-German and Norwegian two-child mothers, time-varying covariate marital status since $2^{\text {nd }}$ birth. 


\begin{tabular}{|l|r|r|}
\hline Marital status since $\mathbf{2}^{\text {nd }}$ birth & West Germany & Norway \\
\hline Never married & $2.26{ }^{* *}$ & 0.84 \\
In the $\mathbf{1}^{\text {st }}$ marriage & $\mathbf{1}$ & $\mathbf{1}$ \\
In a marriage $\mathbf{2}^{\text {nd }}$ or higher order & 2.17 & $2.76 \quad * * *$ \\
Divorced or widowed & 1.00 & 1.40 \\
\hline Newly first married & $2.82^{* *}$ & 1.11 \\
Newly remarried & $3.86^{* * *}$ & $4.49 \quad * * *$ \\
Newly divorced or widowed & $2.03^{*}$ & 0.86 \\
\hline
\end{tabular}

Table 6: Relative risks of third conception dependent on marital status - controlled for: age at first birth, duration between first and second birth, sex of first and second child, size of residence until age 15, educational attainment, educational attainment of the partner, labor force participation, birth cohort 